\title{
The reproduction and publication of Michelangelo's Sacristy: drawings and prints by Franco, Salviati, Naldini and Cort
}

\author{
Raphael Rosenberg
}

Already in 1563, twelve months before Michelangelo's death, Vasari could take it for granted that 'as the whole world knows' the New Sacristy of San Lorenzo 'has been, is and will forever remain the school of the arts', meaning that it was and should continue to be the model for artists. In fact no other site offered as many sculptures by Michelangelo's hand, or, moreover, as varied: seated and recumbent, male and female, draped and naked. It is thus no surprise to ascertain that, of all of Michelangelo's sculptural works, the figures in the New Sacristy from the very beginning attracted the largest number of copyists. A survey of the sixteenth-century copy-drawings shows that examples by more than twenty different hands have survived. ${ }^{2}$ Most of these sheets are studies made by apprentices seeking to learn the art of drawing. Since hitherto collectors have not coveted such 'inferior' works, their preservation is accidental and probably many more are lost. This explains the fact that in the cases of most artists only a single sketch-copy is traceable. However, larger groups of drawings after the statues of Michelangelo's Sacristy survive by three draughtsmen, Battista Franco (c. 1510-61), Francesco Salviati (1510-63) and Giovanni Battista Naldini (1535-91), ${ }^{\prime}$ and these sheets are notable for their unusually detailed and highly finished style. It is the purpose of this essay to discuss these sheets, and to show that their primary intention was not the study but the reproduction of the statues. As we will see, they were used as models for further drawings, for frescoes and particularly for prints. The early history of the printed reproductions of the chapel will therefore be the second focus of the essay. This history that seems to be symptomatic for the figure-oriented reception of Michelangelo's works in the cinquecento begins with two unpublished etchings here attributed to Franco (see Figures 6.3 and 6.4) and culminates in the engravings of Comelis Cort (see Figures 6.9 and 6.10), printed in 1570, a date that will be the chronological limit for this study. 
The construction of a new mausoleum for the Medici family, the New Sacristy' of the church of San Lorenzo, began in 1519 and ended with the death of the main patron, Pope Clement VII, in September 1534. The socalled 'Medici Chapel' was then little more than a well-advanced building site. The architecture of the whole and of both ducal tombs was complete, but only two statues - those of Giuliano, Duke of Nemours, and Lorenzo, Duke of Urbino - had by then been set up. The four Times of Day lay on the floor, and the third monument of the chapel - the tomb for Lorenzo the Magnificent and his brother Giuliano - was not yet built. Michelangelo's unfinished Madonna and Montelupo's St Damian were in a nearby workshop; Montorsoli's St Cosmas was not yet completed. In spite of this unfinished state, interest in the sculptures and in the architecture of the Medici Chapel reached far beyond the confines of Florence. ${ }^{4} \mathrm{~A}$ characteristic example is a letter from Pietro Aretino to Vasari in 1535: he asks his fellow-countryman to send reproductions of the sculptures of both Dukes Lorenzo and Giuliano to him in Venice. Since no prints had yet been produced Vasari probably made drawings, which was the easiest way of reproducing them. In his letter of thanks Aretino is extremely pleased with Vasari's reproductions 'both because you were able to portray them, and because they were made by the God of sculpture'.5

In his Life of Battista Franco Semolei, Vasari relates that in 1536 'all the sculptors and painters of Florence' used to gather in the New Sacristy and study Michelangelo's statues. Franco was then in his mid-twenties, and had just carried out his very first commissions. He stayed for many days in the Medici Chapel, where he made friends with Ammanati and Genga da Urbino. ${ }^{6}$ Seven extant drawings by Franco after the statues of Day, Night and Dawn (see Figure 6.1) vouch for the accuracy of Vasari's information.7 Three of Franco's drawings after the Times of Day are in pen, four in black chalk. All of them have a very detailed and accurate finish, but the fineness of the chalk sheets is rare in his work. ${ }^{8}$ Whereas Franco might have done the pen copies in order to improve his drawing abilities and to collect models for figures that he could use in his own compositions, 9 the aim of the chalk drawings seems to be purely reproductive and the contours of at least one of those sheets, that showing Dawn (see Figure 6.1), was subsequently indented. Either they were done in order to prepare prints after Michelangelo's statues or as equivalents to such prints: Franco might have planned to make prints after all four statues. He did indeed produce at least two plates, after Dawn (Figure 6.2) and Dusk (Figure 6.3), that have remained unnoticed by modern scholars. ${ }^{10}$ Though in the reversed print Dawn is seen more from the right-hand side, there is much in common between this etching and Franco's drawing of the same subject at Windsor: the distribution of the shadows, the way that the muscles are isolated as islands and the heavy, massive and very hard expression of the face. The 


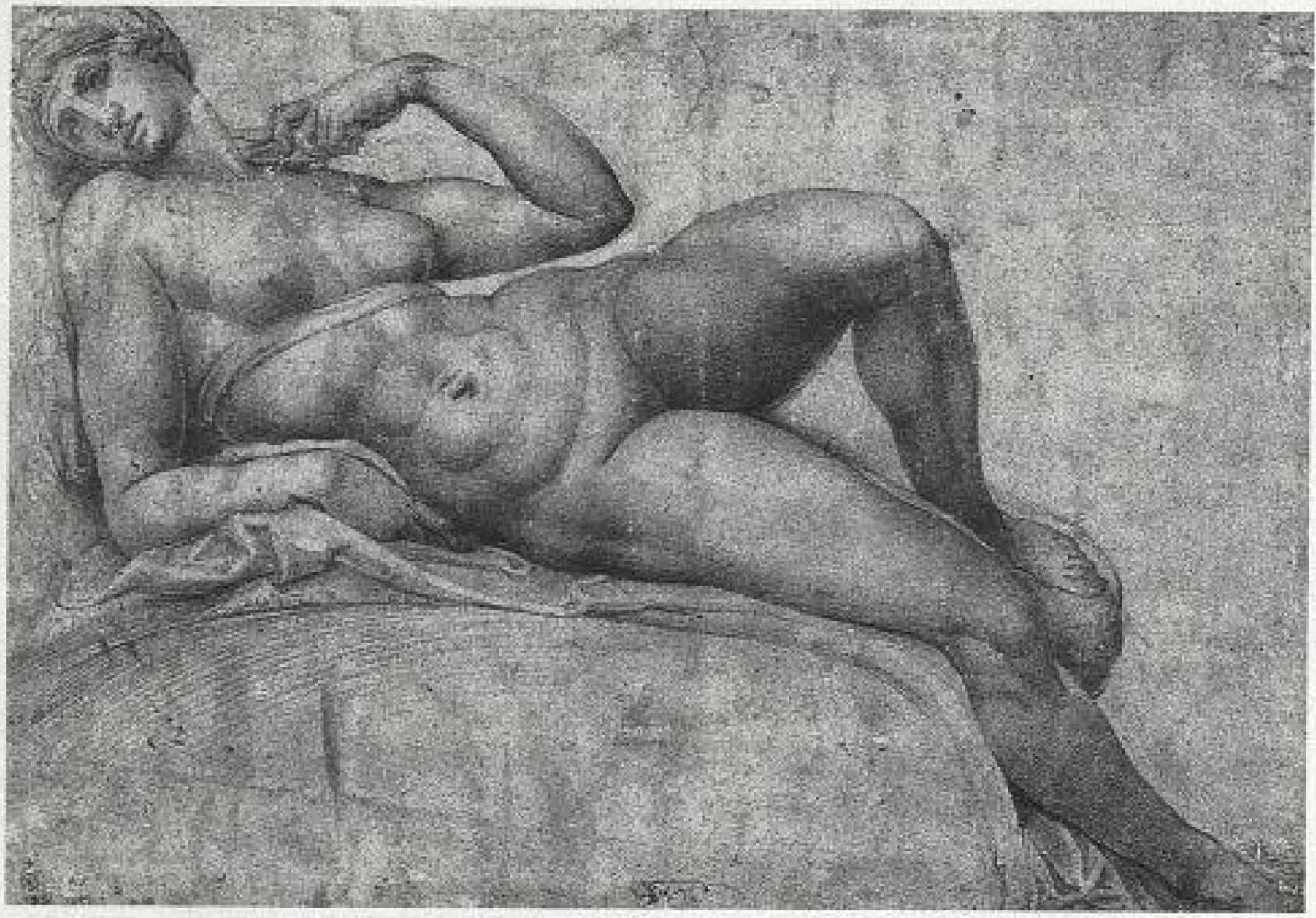

6.1 Battista Franco, Dawn, 1536, black chalk, over stylus indentation, contours subsequently indented

assumption that Franco, among whose works over 100 prints have been identified, "is the author of both plates is confirmed by comparison with some of his other etchings. The Michelangelo copyist's hand shows particularly clearly in the scenic garnishings. No Italian printmaker made such knotty treetrunks, twisted roots and branches as Franco (see Figure 6.3) (compare, for example, B.17, B.24, B.33 - all of them signed with Franco's initials - and especially B.78). Whereas large parts of Dawn's body are engraved, the surroundings are pure etching, a characteristic combination of techniques found in a great number of Battista's prints. Regarding the dating of these prints within Franco's work, it is noteworthy that the print after Dusk is etched throughout, and has no engraved work. This difference suggests that Battista was here experimenting with different printmaking techniques, and I would suggest that they therefore belong to the very beginning of his print work. This, according to recent research, started around 1540 after he had left Florence and returned to Rome, but it may even have been contemporary with his studies in the New Sacristy in $1536 .{ }^{12}$

Whereas Dusk (Figure 6.3) is set in natural surroundings, a curtain separates Dawn (Figure 6.2) from ruined architecture. Like the Windsor drawing (Figure 


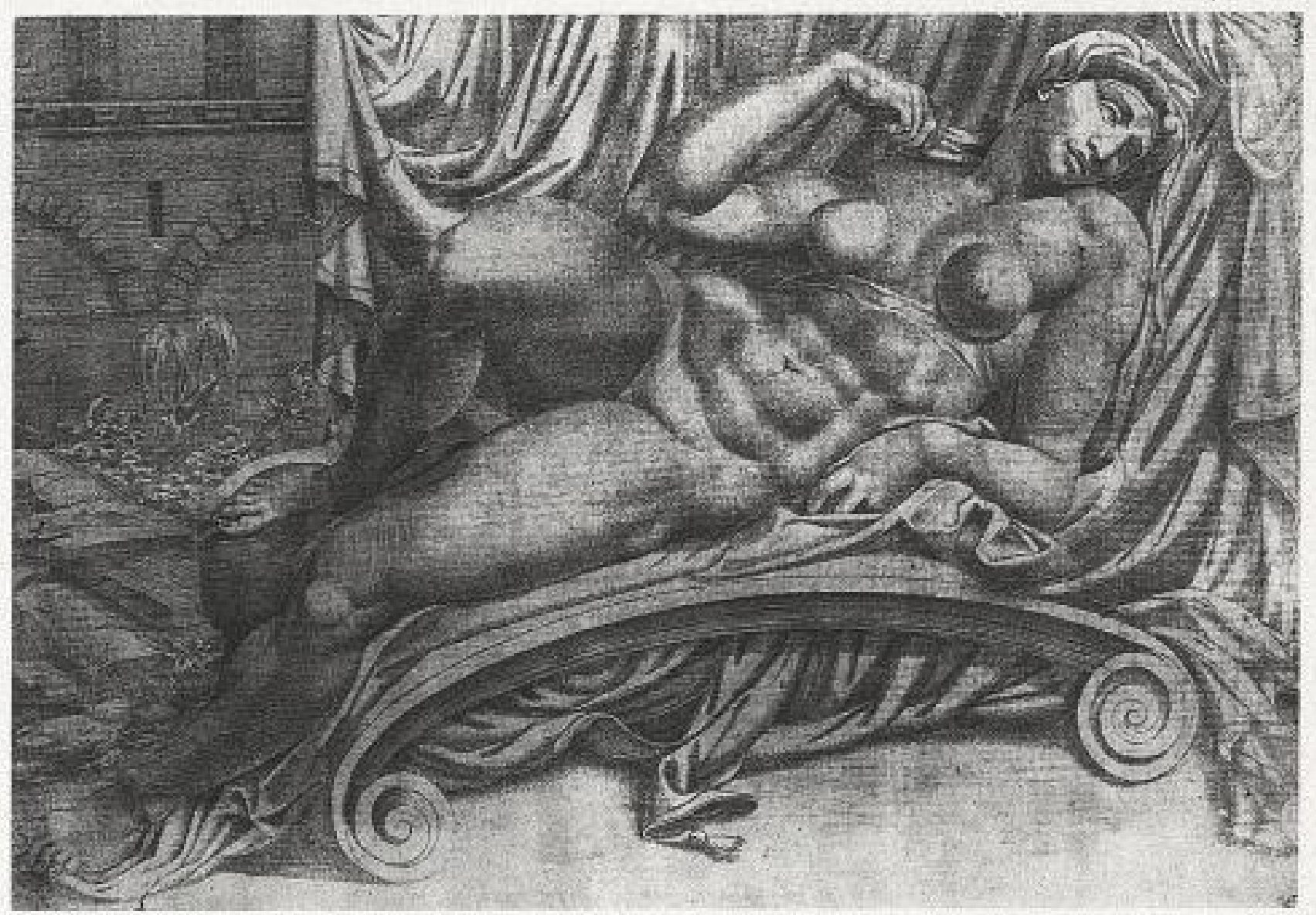

6.2 Here attributed to Battista Franco, Dawn, c.1536, etching and engraving

6.1), both are viewed from an elevated angle, showing that Franco portrayed them before Michelangelo's four statues of the Times of Day were set up above the sarcophagi in $1546 .{ }^{13}$ The volute on which the naked female lies, however, shows that Franco knew about her intended position even though he had not yet seen it. Whenever Franco did those etchings, they are the earliest attempt to publish the sculptures of the Medici Chapel. Moreover, if the suggested dating is correct, they are the very first prints after any of Michelangelo's statues, and one of the earliest reproductions of contemporary sculpture. ${ }^{14}$ In the first half of the cinquecento, prints after statues were indeed almost exclusively limited to antiquities. It is only after the middle of the sixteenth century that, starting with Michelangelo's, the works of modern sculptors began to be diffused through the medium of prints. ${ }^{15}$

The case of Francesco Salviati can be discussed briefly, since all the drawings and prints I refer to are well known. Although an early study after Night in the British Museum (1946-7-13-371r.) was apparently not done from Michelangelo's original statue, ${ }^{16}$ Salviati did make two drawings, one in red and one in black chalk, after Dawn in the New Sacristy itself. These were possibly done in the spring of 1539, during a short sojourn in Florence en route from Rome to Venice. Though they vary significantly in their points of 


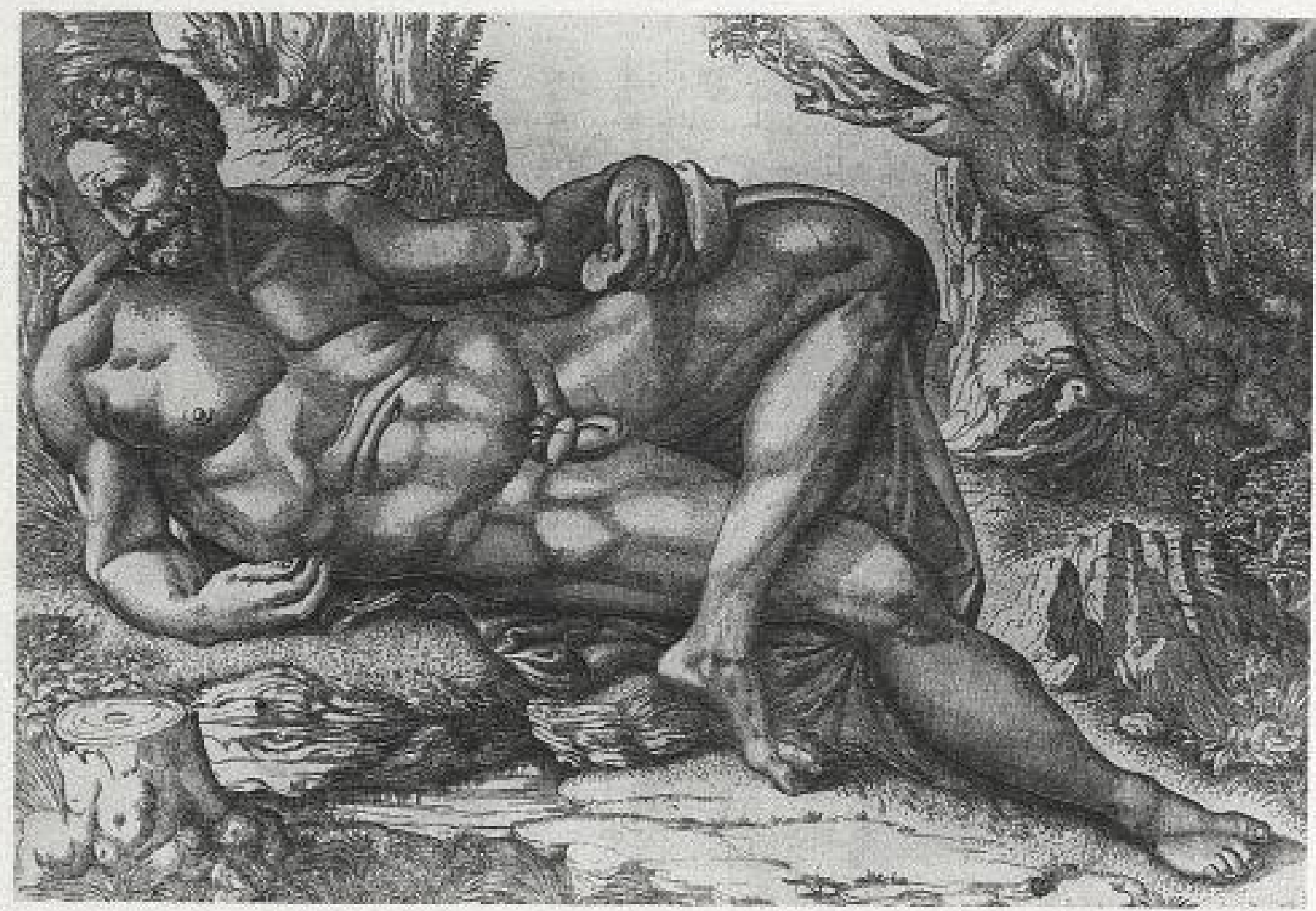

6.3 Here attributed to Battista Franco, Dusk, c.1536, etching

view, both drawings show the statue from above, and without the inclination of the sarcophagus lid, still lying on the floor of the chapel. Both are accurate, though the red chalk sheet in the British Museum ${ }^{17}$ is more finished than that in black chalk in Edinburgh. ${ }^{18}$ The drawing in London is exceptionally inventive not only in its graphic handling, which intensifies the rotative dynamic of Dawn, but also in its unusual viewpoint. As such it is not a neutral reproduction of Michelangelo's sculpture but a skilful, imaginative view of the figure. Salviati's purpose was not the publication of the New Sacristy sculpture; rather, he took Michelangelo's invention as a model for his own designs. Already in 1539 his study of Dawn served as the model for a River goddess in a fresco in the Palazzo Grimani, Venice. ${ }^{19}$ Salviati also used the same sheet for two scenes of Loves of the gods, probably with a print series in view. It was perhaps the pose of Dawn in the British Museum drawing, lying on a diagonal with apparently no contact with the ground, that inspired Salviati to set these two scenes in the heavens. In a drawing now in the Lehman Collection, Michelangelo's figure becomes Io, seduced by Jupiter amongst the clouds which conceal the couple from the jealous Juno..$^{20}$ In a drawing in the Feitelson Collection, ${ }^{21}$ anonymously engraved,,$^{22}$ the London drawing is the model for the cloudy shape of Juno, whom Ixion holds in his 
arms. In a third drawing in Florence, which also appears to be autograph, Dawn (once again inspired by the British Museum sheet) wakes up in a bed while in a landscape background two men walk to work in what could be an allegorical composition of Morning. ${ }^{23}$ The point of view of the Edinburgh drawing makes Dawn appear clumsy. The sheet is less finished, and its reproductive function is therefore less evident, though it might have been used by Salviati in $\mathbf{1 5 5 4}$ for his figure of Springtime in Santa Maria del Popolo, Rome, ${ }^{24}$ and again in Rome around 1580 by Jacopo Zucchi for his easel painting The Golden Age. ${ }^{25}$ Neither Salviati nor Zucchi, however, faithfully reused the drawing, but it was faithful enough to serve in 1671 as the prototype for an etching printed by Jan de Bisshop in his Paradigmata, in which the Dutchman knew that he was reproducing a statue by Michelangelo after a drawing by Salviati. ${ }^{26}$

Before continuing we should consider the further history of the New Sacristy. In March 1537 Duke Alessandro de' Medici was buried in the sarcophagus of his presumed father Lorenzo, Duke of Urbino. The corpses of Lorenzo himself and his uncle Giuliano, Duke of Nemours, had probably been moved into their sarcophagi by that time. These three were the very last descendants of a glorious branch of the Medici family, that of Cosimo 'il Vecchio' and Lorenzo the Magnificent. For Duke Cosimo I, who had taken power in 1537, those buried in the chapel were important predecessors but only distant relatives, and he was in no hurry to finish their mausoleum. As already mentioned, the statues of the Times of Day were set up above the sarcophagi in 1546; in 1556 the windows of the chapel were glazed and the walls between the pilasters were plastered and whitewashed. In 1559 the earthly remains of Lorenzo the Magnificent and his brother Giuliano were translated to the chapel, and at this point the three statues that had been brought here in 1546 were finally installed on their tomb. Thus, only forty years after work had started the building site appeared approximately as it is today. Finally around 1561 the religious services, the liturgy of perpetual intercession that Clement VII had ordered thirty years earlier, were started. Shortly after the New Sacristy had become a functioning chapel, Vasari and Vincenzo Borghini were permitted to hold the meetings of the newly founded Accademia del Disegno in the Convent of San Lorenzo. They probably gathered in the chapel for masses, and many of them studied, making drawings and models after Michelangelo's statues while the priests sang the liturgy. When Michelangelo died in 1564 it was this Florentine Academy that organized a splendid public funeral in the church of San Lorenzo. ${ }^{27}$

Among the young artists who under the auspices of the Accademia del Disegno drew intensively in the New Sacristy at this time, Giovanni Battista Naldini is the easiest to trace. ${ }^{28}$ And the number - approximately two dozen - of extant drawings of the New Sacristy statues by and after Naldini is 
exceptionally large. Among them it is useful to distinguish three groups, probably belonging to different phases ${ }^{29}$ and certainly done for different purposes. Comparison between these groups makes very clear the general difference between drawings done for study and copies executed for reproductive purposes.

A first group of drawings includes detail studies of the head of Dawn, ${ }^{30}$ as well as of the head ${ }^{31}$ and right hand ${ }^{32}$ of Giuliano de Medici. These studies were apparently not executed in front of the original statues, nor after threedimensional copies of them, but from casts that only reproduced those parts of the statues. ${ }^{33}$ They are rather small sheets in red or black chalk, occasionally heightened with white. The outlines are heavy as a result of having been traced repeatedly; the internal modelling is limited to few details; and careless hatching like the weave of a brittle, rough rug creates dark areas around the forms. These very rapidly drawn sheets were certainly meant as drawing exercises in general and more specifically as training in foreshortening, and they were probably done at an early stage of Naldini's career.

At least three other sketches - one in the Albertina, ${ }^{34}$ one in the Louvre ${ }^{35}$ and one sold in 1974 at Sotheby's (see Figure 6.4) ${ }^{36}$ - showing the entire statue of Lorenzo de' Medici were executed in the New Sacristy itself. They show the niche behind the statue, and it is possible to discern the head of Dawn (in Figure 6.4) and of Dusk (in the Albertina drawing) at the bottom left and right. Their style is close to Pontormo, and in fact the Albertina sheet has often been attributed to Naldini's teacher himself. Compared with the first group they seem to be more advanced, hasty but also assured and loose; and the diagonal hatchings are more uniformly distributed within and around the figure. I would therefore date them later. These too are certainly drawing exercises, but it is worth noting that copies were made at this time after studies of this type: an unpublished drawing formerly in Reynolds's collection appears to be a copy after the sheet illustrated here by a draughtsman who might have been a pupil of Naldini. ${ }^{37}$

Two large sheets in Princeton (see Figures 6.5 and 6.7 ) $^{38}$ and one in Windsor ${ }^{39}$ differ in their very finished, almost miniature-like style from the sketches discussed above, and this difference has puzzled many scholars..$^{40}$ Their highly polished style is indeed hard to compare with anything that is known of Naldini's chalk drawings. Bean, Feinberg and Pilliod have remarked that the typical Naldinesque, and of course Pontormesque, 'wavering superimposed contours ${ }^{41}$ are to be seen at least in some details, such as in the hands and, especially, in the left foot of Giuliano de' Medici (see Figure 6.5). This foot happens to be exactly the part of the figure which Naldini could not see while he was drawing, because it was obscured by the head of Day. After faintly sketching the outline of the head he probably moved so as to observe the hidden detail, and withdrawing into what can be considered 


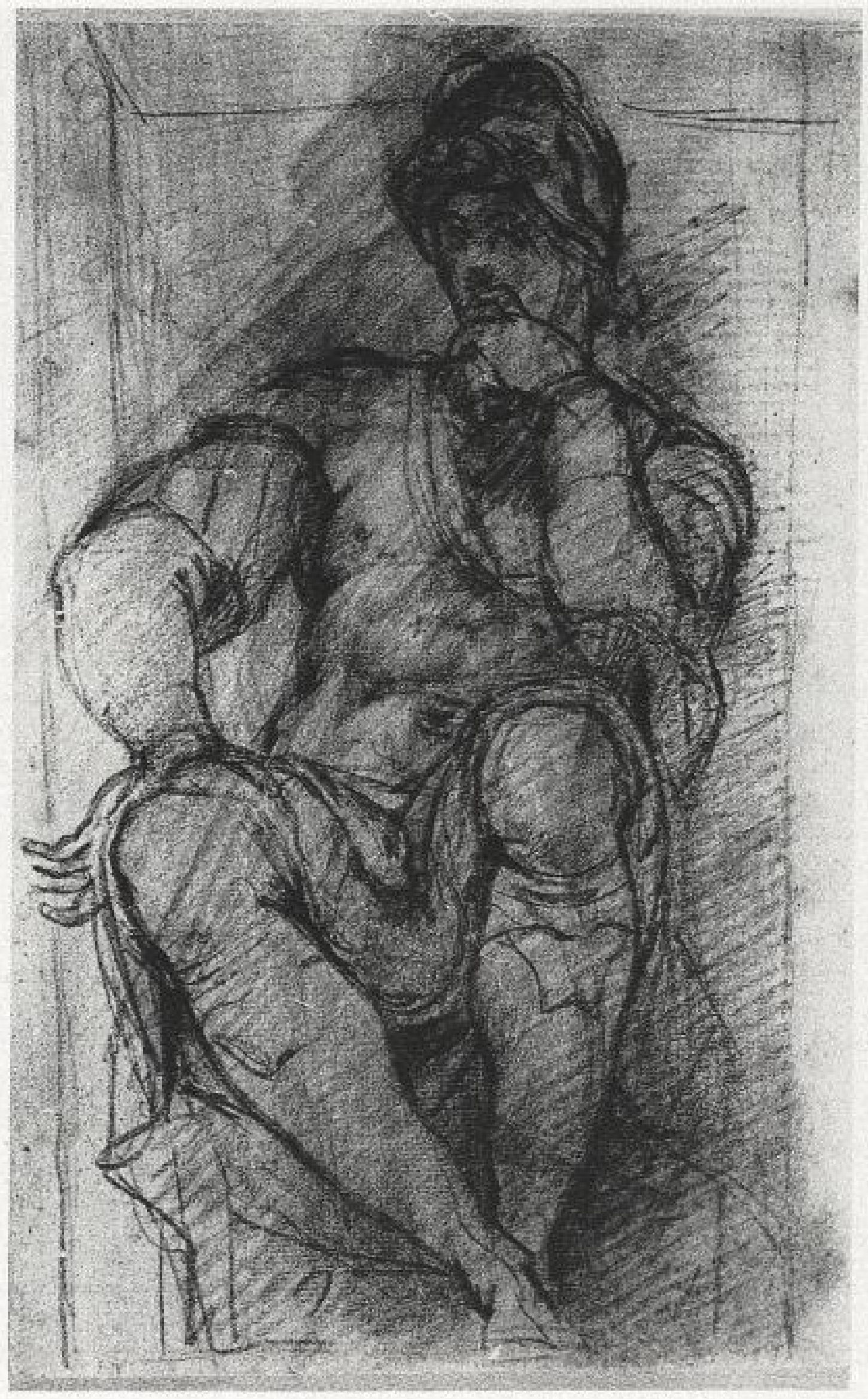

6.4 Giovanni Battista Naldini, Lorenzo de' Medici, c.1560, black chalk over red chalk 


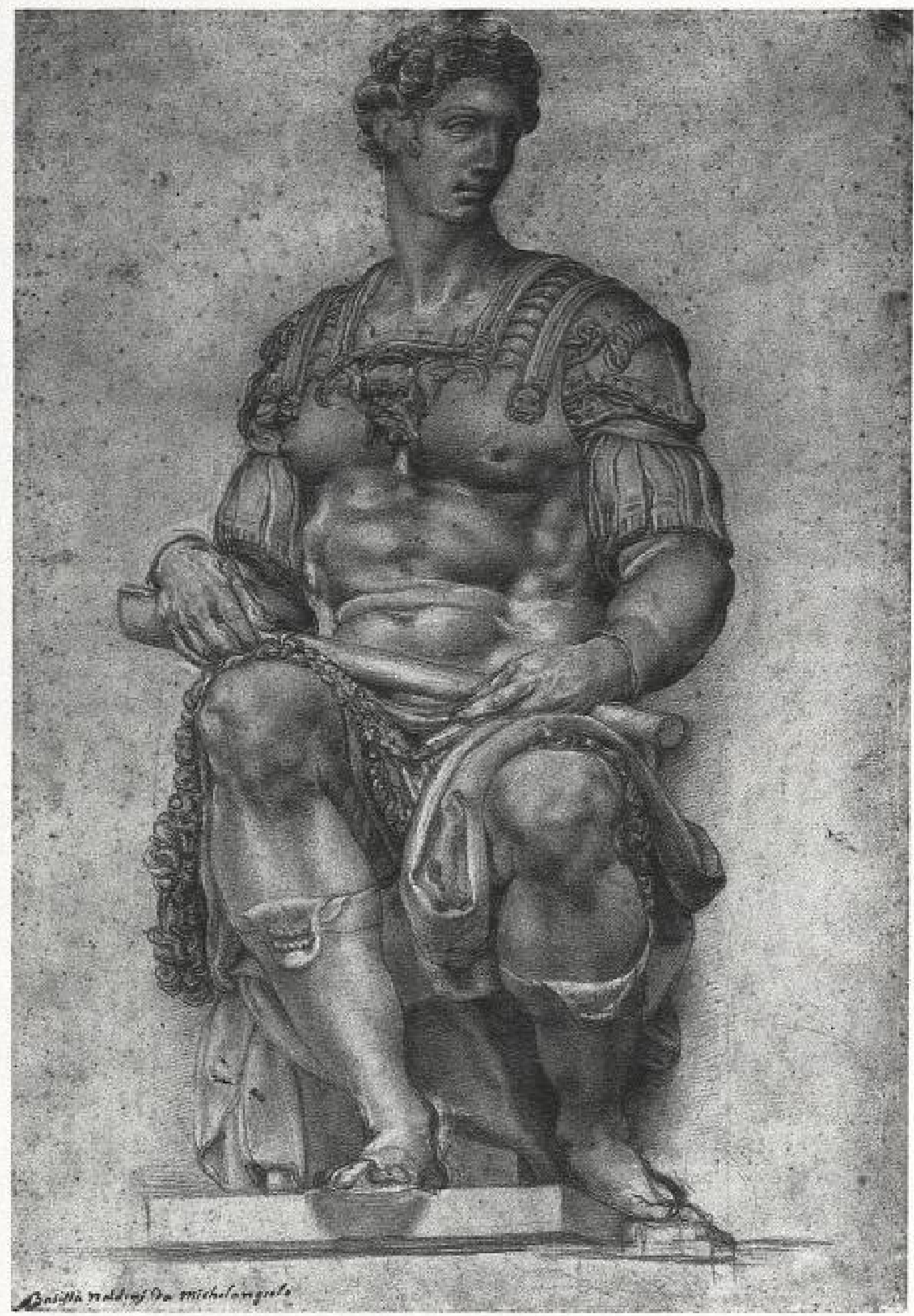

6.5 Giovanni Battista Naldini, Giuliano de' Medici, before 1570 , black chalk, heightened with white, on brownish paper 


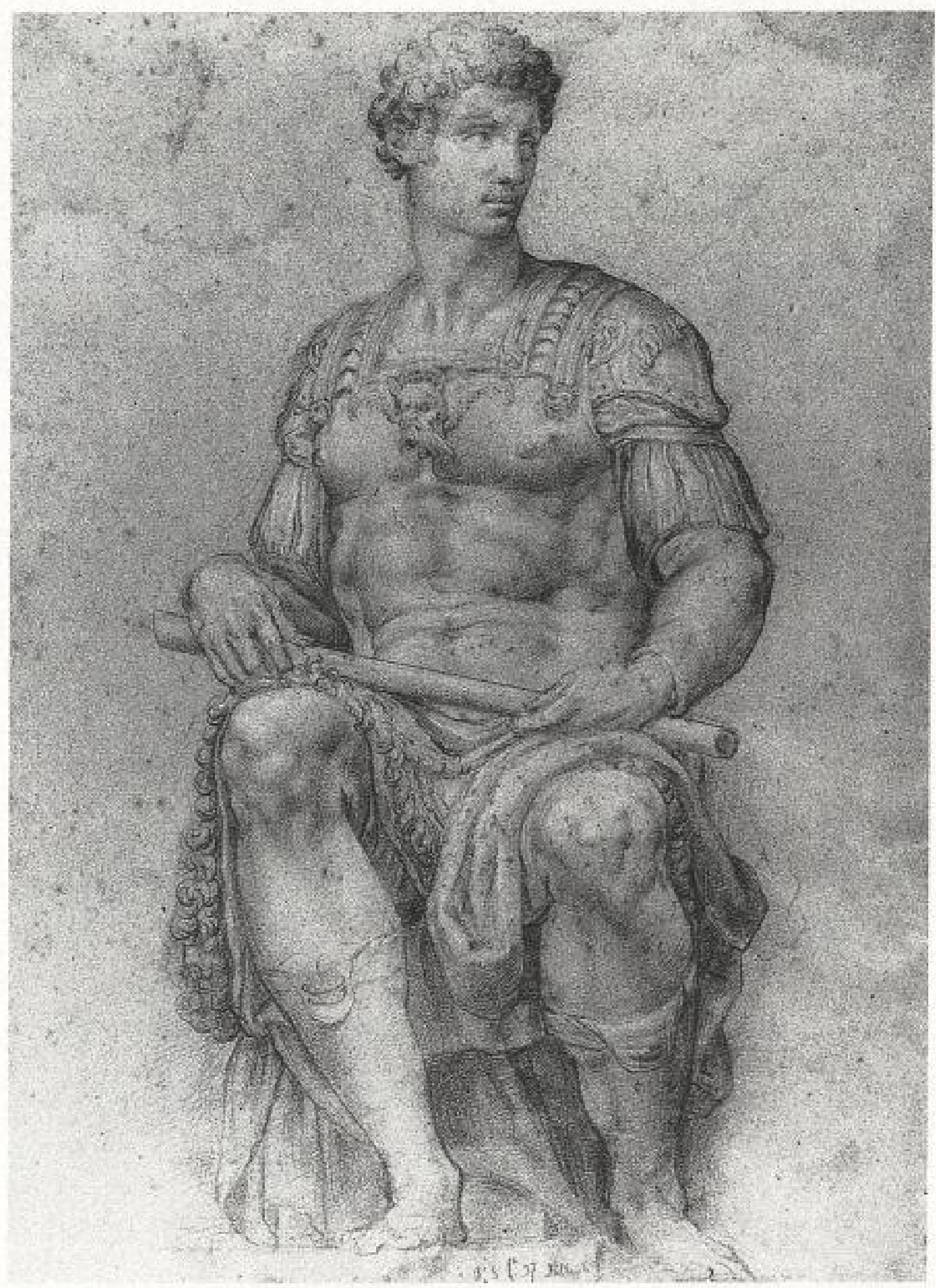

6.6 Anonymous, copy after Naldini, Giuliano de' Medici, c.1580, black chalk, heightened with white, on blue paper 


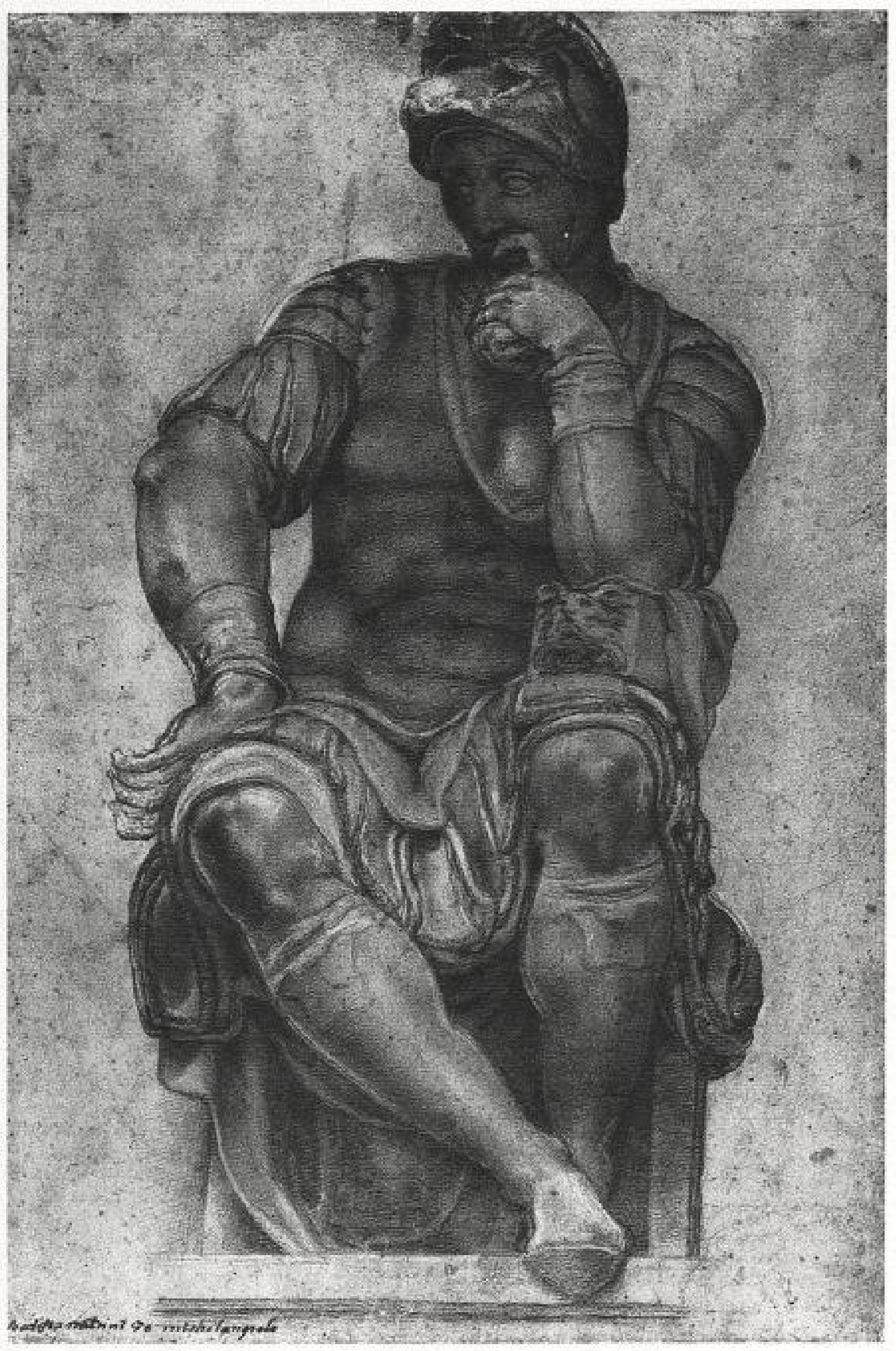

6.7 Giovanni Battista Naldini, Lorenzo de' Medici, before 1570 , black chalk heightened with white, on brownish paper 
his typical 'approximative' style he provided only an indication of it. This detail helps to confirm the attribution to Naldini given by sixteenth-century inscriptions at the bottom of both Princeton sheets, an attribution that has been generally accepted by most scholars. The connection between both capitani in the Princeton sheets and Naldini's drawing after Night at Windsor is confirmed by the fact that copies of them all are to be found in an unbound album in Lille (see Figure 6.6). This album, which originally had at least 51 sheets, was drawn by a single hand, probably a Florentine artist, and can be dated on stylistic grounds and by watermarks to around 1580 . It was apparently made up entirely of copies of drawings or engravings, systematically arranged, after what at the end of the cinquecento may have been considered the canonical examples of art works in Florence. As well as the copies after the seven statues by Michelangelo in the New Sacristy (but none after the St Cosmas and St Damian by Montorsoli and Montelupo who sit right and left of the Michelangelo Madonna and Child), it contains complete illustrations of Andrea del Sarto's frescoes in the Chiostro dello Scalzo and in SS Annunziata, and of Salviati's frescoes in the Sala dell'Udienza of the Palazzo Vecchio. There is also a less complete set of copies after Raphael's frescoes in the Loggia di Psiche. ${ }^{42}$

Comparisons between the sheets at Windsor or Princeton (see Figure. 6.5) and their counterparts in Lille (Figure 6.6) show that the Lille drawings are less detailed, flatter and weaker than Naldini's originals, and that wherever they differ from them they also diverge from Michelangelo's statues: compare, for example, the mask on Giuliano's chest, or the folds of drapery between his knees. It is also worth noting that the only part of the Lille sketch that is more detailed than the Princeton drawing is Giuliano's left foot. The Lille copies after Dawn (w. 2363), Dusk (w. 2367) and Day (w. 2368) are stylistically so similar as to indicate that they copy lost drawings by Naldini that originally formed a larger set of which the sheets in Princeton and Windsor have survived. ${ }^{33}$ This group of drawings is of course far from photorealism: Naldini for instance changes the proportions and draws Giuliano's legs (see Figure 6.5) as much broader than those of Michelangelo's figure. Nevertheless, they are the most exact reproductions of those statues ever done before the 'Age of Mechanical Reproduction'. And the unusual shine of the highlights in these drawings even reproduces the gloss of the marble. The fact that a whole set of big drawings was produced, and that they were meticulously copied, demonstrates that Naldini's aim in this case was not the study but the reproduction of Michelangelo's sculptures; this particular aim fully explains their unusual style. Further explanations, such as that of Zygmunt Wázbiński who described the Princeton drawings as 'academic' and is convinced that both sheets were done for a competition to enter Vasari's Accademia del Disegno, may be discarded without hesitation since there are 
no indications that such competitions took place, or that any drawings were used for such purposes in the 1560 s. $^{44}$

To understand the interest taken by contemporaries in good reproductions of the statues of the New Sacristy it is helpful to realize that by the time of Michelangelo's death most of his Roman works had already been published by means of the print medium. Single figures from the vault of the Sistine Chapel were engraved by Marcantonio Raimondi immediately after the frescoes had been completed, and prophets, sybils, ignudi and even the figures from the lunette and vaulting cells had been systematically reproduced several times, together with the Last Judgement, since the $1540{ }^{45}$ Prints of many of his statues (the Bacchus, ${ }^{46}$ the Pietà in St Peter's, ${ }^{47}$ the Christ in Santa Maria sopra Minerva ${ }^{48}$ and the Julius Tomb ${ }^{49}$ ) were also available by then. Prints of several drawings of his frescoes in the Cappella Paolina ${ }^{50}$ and of some of his architectural projects in Rome were likewise on sale. ${ }^{51}$ On the other hand, no prints of Michelangelo's Florentine works yet existed, except for details from the (by then already lost) Battle of Cascina cartoon and the two etchings by Franco (see Figures 6.2 and 6.3). There were no prints after the David, or the David-Apollo, none after the early tondos, none after the works still in his Florentine studio (the early reliefs, the Victory, and the unfinished Slaves), and none after the New Sacristy in its totality. One of the probable reasons for this contrast is that a group of reproductive print publishers had started working in Rome who were systematically publishing the monuments of the city, and who had no counterpart in Florence. ${ }^{52}$ Although the Medici Chapel had always attracted an enormous amount of interest, a comprehensive reproduction of it was only realized in 1570 by Cornelis Cort (1533-78), a Dutchman who had settled in Rome in 1566 as a free-lance engraver, and was there producing engravings for different publishers. ${ }^{53}$ Two prints by his hand give orthogonal views of the Tombs of Dukes Giuliano (Figure 6.8) and Lorenzo (Figure 6.9). ${ }^{54}$ They belong to a series of four engravings dated 1570: another shows the third tomb of the New Sacristy, the monument for Lonenzo il Magnifico and his brother Giuliano., $\mathrm{A}$ fourth print illustrates the Tomb of Piero and Giovanni de' Medici, made by Verrocchio in 1472 and set in a window-like opening in the wall between the Old Sacristy and the Chapel of Sts Cosmas and Damian in the church of San Lorenzo. ${ }^{56}$

Cort's prints are a fairly accurate representation of the architecture and the ornaments of the tomb monuments, and the gradual shading renders the three-dimensionality of Michelangelo's work remarkably effective. Even the placement of light and shade reflects the original situation in the chapel on sunny days, although in place of a purely frontal lighting Cort implied a more customary light source above and to the left. Nevertheless the figures, especially those of the Lorenzo de' Medici Tomb, are oversize, and a careful comparison demonstrates that each one is seen from a different angle of 


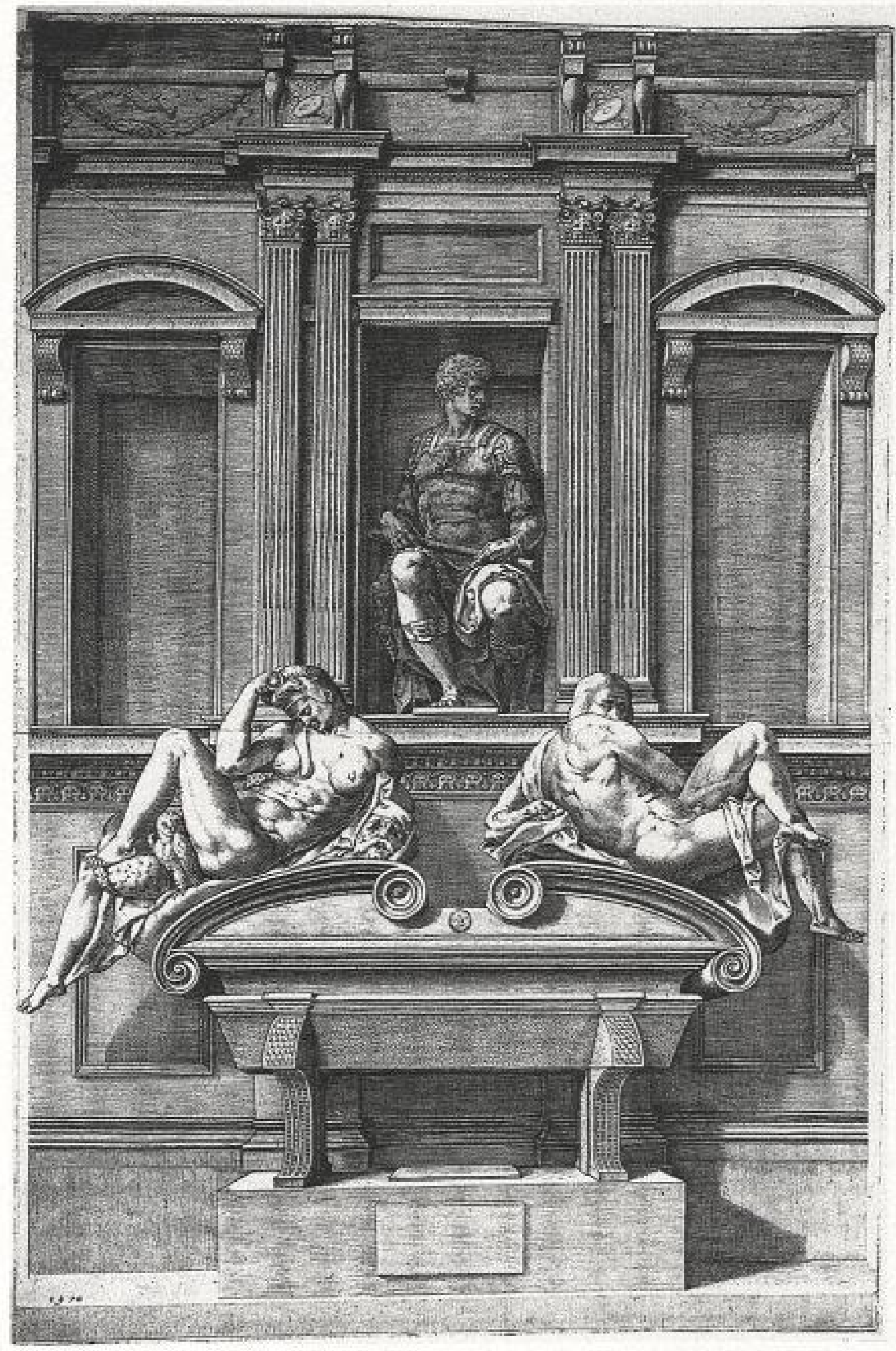

6.8 Cornelis Cort, Tomb of Giuliano de' Medici, 1570, engraving, state I 


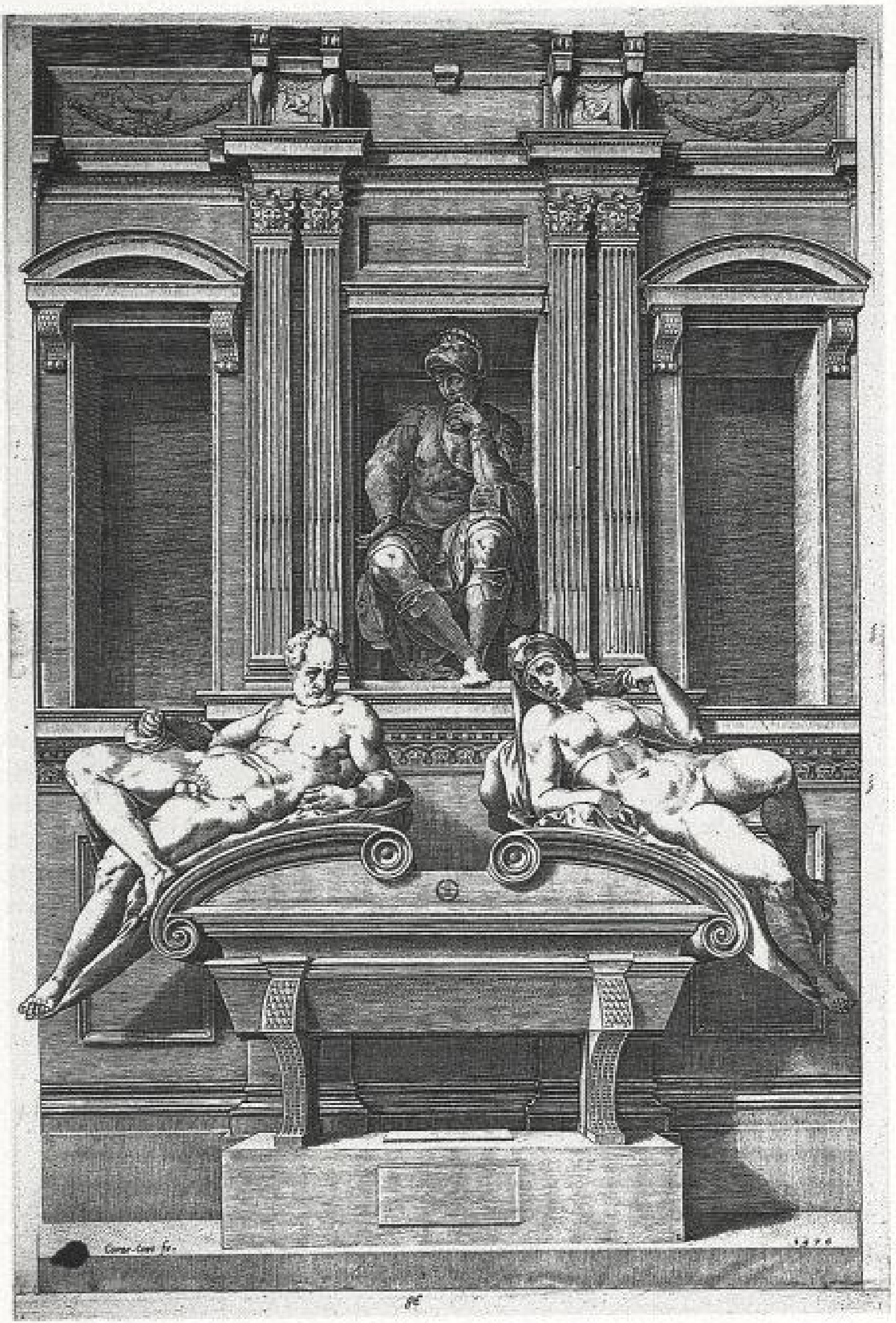

6.9 Cornelis Cort, Tomb of Lorenzo de' Medici, 1570, engraving, state I 
view: Lorenzo de' Medici and Dawn from the right-hand side, Dusk almost frontally. However both engravings match up with the points of view of the Naldini drawings in Princeton and Windsor, as well as those of the copies in Lille. ${ }^{\text {7 }}$ Furthermore, wherever Naldini - although minimally - diverges from Michelangelo's figures, Cort follows him. This applies for instance to the oversized drapery folds to the left and right of Lorenzo de' Medici's knees and to the strap on his right shoulder, which is absent from Naldini's drawing (see Figure 6.7) as from Cort's engraving (see Figure 6.9). Though Cort shows Giuliano de' Medici's head in profile (see Figure 6.8), he copies the drapery folds between his knees that Naldini (see Figure 6.5) rendered in a more elaborate manner than Michelangelo had carved them. It is therefore evident that Cort used Naldini's drawings now in Princeton and Windsor, or at least very good copies of them, to design his plates. One of the most convincing pieces of evidence for this is the rendering of the head of Day. Naldini had to face the problem of how to draw this unfinished part of the statue. Judging by the copy of his drawing in Lille, he could not decide whether to show the 'non finito' and its expressive power or whether to complete it. ${ }^{58}$ Correspondingly Cort's engraving (see Figure 6.8 ) shows the same awkward solution. The converse possibility that Naldini made his drawings after Cort's engravings must be ruled out since his big sheets are much more detailed and closer to Michelangelo's statues than the prints. Cort obviously composed his prints from single drawings of every sculpture and must have had a general drawing of the architecture that has not yet been traced. ${ }^{59}$

It is hard to say whether Naldini made his set of reproductions expressly for Cort. The comparison with the engravings shows that his sheets are much bigger and far more detailed than Cort required. They bear no sign of transfer; they are not indented, nor squared, nor have they faded through counterproofing. If, as I suppose, it was Cort who ordered the drawings, he may originally have planned to make prints of each statue on its own, or he may have failed to explain accurately enough what he needed. Unfortunately no written sources are known for the circumstances surrounding Cort's engravings: all we know is that he made an engraving of the Medici family tree for Cosimo I in $1569 .^{60}$ Whereas the printing of the family tree clearly served the Grand Duke's interests, the purpose of the series with the four Medici Tombs is unclear. Were they simply illustrations of one of the most renowned works of the only recently deceased and divine Michelangelo, as well as of the refined technique of Verrocchio? Or were they intended to glorify four generations of predecessors of the ruling Duke? Cort's prints in their original state are signed and dated, ${ }^{61}$ but they do not carry any explanatory inscriptions. It is only in 1621 , as the copper plates were to be republished, already for the sixth time, by a Roman printer, that factual 
inscriptions mentioning the person commemorated, the iconography of the statues and Michelangelo as the architect and sculptor were added to them. ${ }^{62}$ Borea, Meijer, Corti and Sellink have suggested that Cosimo I himself commissioned the prints from Cort. ${ }^{63}$ Wázbinski, on the other hand, assumed that it was the Accademia del Disegno that commissioned them; ${ }^{64}$ but there is no documentary evidence for either claim. Had the series of the four Medici Tombs been an official commission of the Grand Duke, of his family or of 'his' Academy, it might be expected that the Tombs of the Medici Popes Leo $\mathrm{X}$ and Clement VII, and also that of Giovanni delle Bande Nere, Cosimo I's father, commissioned by the Grand Duke from Bandinelli, would have been included. Also, the fact that the plates for the four prints fell into the hands of the Roman publishers, while the family tree (which was updated in 1589) certainly remained in Florence, ${ }^{65}$ speaks against an official commission. It is more probable that Cort used his Florentine sojourn to prepare prints after these exceedingly celebrated monuments on his own account. The motivation for this would have been the entirely justified hope that henceforth he would win customers who were both enthusiastic about Michelangelo's art and interested in the history of Florence and its princes. But it is also conceivable that he hoped for a grand-ducal commission, and therefore for the time being left the space for the inscription blank.

To bring my discussion to a close I would like to return to Franco's etchings, and compare them with Cort's prints. For Franco, the sculptures were free of the context of the funerary chapel. Each one is set separately in apparently arbitrary surroundings. Dusk (see Figure 6.3) lay like a river-god on the bank of a stream, surrounded by trees and rocks. Because of his downwarddirected glance, he looks more like a Narcissus than an image of evening. There is nothing to lead the ignorant beholder of the etching to the assumption that he may be dealing with the representation of a marble sculpture. The etching of Dawn (see Figure 6.2) also hardly suggests the stony nature of the original. She lies on a volute as in the current arrangement, and her angular leg is resting on something that might be a rounded stone. However there is a curtain behind her. In the middle-ground on the left one can make out a few mossy flagstones and shrubs, and behind this a wall with rusticated arches, a console cornice and pillars. This vista serves less as an environment for the figure: it is rather its attribute, for the antique character of the ruins ennobles the contemporary sculpture. ${ }^{66}$

This ennoblement is all the more understandable if one bears in mind that these etchings are among the earliest printed reproductions of non-classical sculpture. That Franco has alienated the sculptures from their context can be explained on the one hand by the fact that at the time of his sojourn the sculptures were not yet mounted in their locations on the monuments. The reproduction of this condition was obviously out of the question, and Franco 
might have lacked the understanding to make a reconstruction of the intended arrangement. On the other hand, it is a characteristic of the early printreception of Michelangelo that single figures and not entire compositions are given preference. Around and shortly after 1510 Marcantonio Raimondi and Agostino Veneziano repeatedly placed selected figures both from the Battle of $\mathrm{Cascina}^{67}$ and from the Sistine Ceiling ${ }^{68}$ in inappropriate landscapes. In general it is striking that amongst the numerous copies no single complete reproduction of the Battle of Cascina has survived. Moreover, whereas the single figures of the Sistine Ceiling were reproduced in several series, the central images with stories from Genesis were not completely reproduced until the eighteenth century. ${ }^{69}$ Likewise, amongst the very numerous copydrawings after the sculptures of the New Sacristy in the whole of the cinquecento there is not one single complete view of the ducal tombs. Cort's prints are in this respect a complete exception, but it is characteristic that these were put together from individual drawings and from varying points of view. They are nevertheless an especially high-quality example of the objective style of graphic reproduction typical from the mid-sixteenth century, ${ }^{\circ 0}$ and they remained the standard reproductions of the chapel until the eighteenth century. ${ }^{72}$

\section{Acknowledgements}

This essay is based on a catalogue of drawings after the sculptures of Michelangelo that has meanwhile been published in German (Rosenberg 2000). I am very grateful to Paul Joannides and Rhoda Eitel-Porter with whom I had the opportunity to discuss many of the issues considered here, and to Francis Ames-Lewis who helped a lot to find a convenient English form for them. I am also grateful to Aidan Weston-Lewis who pointed out to me several drawings discussed herein; to Barbara Brejon de Lavergnée for her support in-Lille; to Barbara T. Ross who has studied the Naldini sheets in Princeton in order to answer my questions; to Steffen Egle who had a close look at the Franco etchings in Berlin; and to Anne Varick Lauder for sharing her expertise on Franco. I owe a last 'thank you' to those who, after the symposium in London, enriched this paper through their suggestions and questions: William Wallace and many others who remain anonymous.

\section{Notes}

1. Letter of Vasari to Cosimo I of 16 February 1563: 'Ella [Cosimo] con tutto il mondo sa, ch' ell' [the New Sacristy] è stato, è et sara, fin che durerann gli annj, la scuola delle nostre arti', in Frey 
(1923-40), I, 719. A very similar wording already occurs in his letter to Cosimo of 1 February 1563 (Frey (1923-40), 1, 712).

2. For comparison, it is interesting that for the same period I was able to trace drawings by a dozen different artists after the sculptures of the Julius Tomb, three after the St Peter's Pietd and only two sheets directly done after the David, Compare Rosenberg (2000), 201-54 and Joannides in exh. cat. Washington, London and elsewhere (1996-98), 139.

3. Elisabeth Pilliod has discovered new documents demonstrating that Naldini was born in 1535 and not 1537. See Joannides in exh. cat. Washington, London and elsewhere (1996-98), 201.

4 For a detailed account of the history of the chapel, see Rosenberg (2000), 127-45.

5. '... si perche havete saputo ritrargli, si perche vengano da lo iddio de la scoltura', in Frey (192340), I, 35. Vasari's drawings seem to be lost.

6. -... si mise Battista [Franco] a disegnare con grandissimo studio le statue di Michelagnolo che sono nella sagrestia nuova di San Lorenzo, dove allora essendo volti a disegnare e fare di rilievo tutti i scultori e pittori di Firenze ... Dimorando dunque Battista in fra gli altri, e frequentando la detta sagrestia, fece amicizia con Bartolomeo Amannati scultore, che in compagnia di molti altri la studiavano le cose del Buonarroto'; Vasari (1966-87), V, 460-61. According to Vasari this happened after the entry of Margaret of Austria, the wife of Duke Alessandro, into Florence ( 31 May 1536) but before the assassination of Alessandro ( 5 January 1537). For a fundamental discussion of Franco's relation to Michelangelo see Anne Varick Lauder's chapter in the present volume (Chapter 5).

7. After Day: Budapest $\mathrm{k} .67 .34$, Uffizi 14778r, Louvre 750, 751r., and 751v. (originally on separate sheets); after Night; Louvre 749; and after Drww: Windsor RL 0428; see Rosenberg (2000), NZ 193-9 and Joannides in exh. cat. Washington, London and elsewhere (1996-98), no. 43 -

8. Anne Varick Lauder, who is currently preparing a catalogue of Franco's drawings, confirmed in a letter of October 2001: 'There are numerous examples of Franco's drawings after the antique, nearly all of which are executed in pen and brown ink, occasionally with some underdrawing in chalk, but they do not display nearly the same degree of finish seen in the four chalk drawings after the Times of Day.'

9. Lauder gives several examples of Franco's use of Michelangelo's figures in her contribution to the present volume (Chapter 5). On borrowed figures in the cinquecento see also Irle (1997). Interestingly Vasari denotes Franco's involvement with Michelangelo as study ('studiare') and imitation ('cercare d'imitare'): 'Battista Franco .... si risolve non volere altre cose studiare ne cercare d'imitare che i disegni, pitture e sculture di Michelagnolo'; see Vasari (1966-87), V, 459.

10. Charles de Tolnay might have known them since he laconically enumerates among the 'copies of the figures of the Medici Chapel ... Engravings by an anonymous master of the mid-sixteenth century, representing Crepuscolo and Aurora in a landscape. Paris, Bibliotheque Nationale'; De Tolnay (1943-60), III, 155. The impressions reproduced here are at the Kupferstichkabinett of Berlin (Dusk: inv, no, 65-102, 307 × $443 \mathrm{~mm}$; Dawn: inv. no. 64-102, 305 $\times 451 \mathrm{~mm}$ ). Both are fine, mostly trimmed along the borders, with a damage in the paper at Dusk's left hand.

11. Most of them were listed in Bartsch (1803-21), XVI, $109-60$, and are reproduced in The Illustrated Bartsch, XXXII, 156-246. A modern and complete catalogue raisonné does not yet exist. Van der Sman (1994) gives a good summary of the state of research.

12. See Salvadori (1991), 15of, Parma Baudille (1994), 91, and Van der Sman (1994), 103. The chronology of Franco's prints is very difficult to reconstruct since none bears a date, and it cannot be excluded that he had already begun to make prints in the middle of the 15305 in Rome. In his later intaglios (according to Van der Sman (1994), 107, dating to the second half of the fifth decade) Franco developed intense darkness through etching and differentiated very clearly the expressive possibilities of both techniques. Nothing of this is to be found in the etchings discussed here, in which he rather seems to be learning how to use the techniques.

13. By Tribolo in December 1546; see Rosenberg (2000); 132-4.

14. The only earlier one that I know is the print by Master NA.DAT with the Mousetrap, which includes Andrea Sansovino's Madonna and St Anne from Sant' Agostino: The Illustrated Bartsch, XXV, 238. Compare Hind (1938-48), V, 266, and Borea (1979), 394.

15. Unfortunately no general studies on this question yet exist. First steps were taken by Baljöhr; she considers the two engravings of Michelangelo's St Peter's Pieta (1547; compare note 47, this chapter) to be the earliest prints after a non-antique sculpture; see Baljohr (1990), 4,40 and passim.

16. Compare the article by Paul Joannides in the present volume (Chapter 4). 
17. London, British Museum, 1900-8-24-118; see Rosenberg (2000), NZ 414, pl 11, with bibliography.

18. Edinburgh RSA 863; see Joannides in exh. cat. Rome and Paris (1998), 96-7 cat. no. 8 (repr.) and Rosenberg (2000), NZ 413 , pl. 9 . Both sheets certainly predate December 1546 , when Tribolo set up the sculptures on the sarcophagi (see note 13, above, this chapter). The drawing in the British Museum was used as a prototype in the Grimani frescoes as early as 1539; see Hirst (19631), 156. Paul Joannides has accepted Hirst's dating of 1539 for the British Museum drawing, and argues that the Edinburgh sheet is stylistically more advanced and should be placed at around 1546. However, it seems to me difficult to accept that Salviati could have drawn from the sluggish position of the Edinburgh sheet after having adopted the unusual and dynamic viewpoint used for the British Museum drawing. I would therefore rather suggest that the Edinburgh study was done just before the other one, and would explain the difference between them by their intention rather than by the date. The higher finish of the red chalk sheet in London might be explained by the fact that Salviati was more definite in using it for reproduction purposes, and indeed he took it several times as a prototype for his own inventions.

19. Hirst (1963a), 156 (repr.).

20. New York, Metropolitan Museum of Art, Lehman Collection, 1975-1.321r. See Forlani Tempesti (1991), 278-81 (repr.), with bibliography; Forlani Tempesti thought the drawing might have been destined to be transferred to a fresco, and suggested an attribution to Salviati. Mortari (1992), 241, no. 403, repr, confirmed this view. Although no print after this drawing is known, the comparison with the sheet in the Feitelson Collection that has almost exactly the same dimensions suggests a similar purpose (Jupiter and Io: $23.6 \times 17.9 \mathrm{~cm}$; Juno and Ition: $25,3 \times 17.3$ $\mathrm{cm})$.

21. Feitelson Collection at the University Art Museum of Santa Barbara. First published by Richard Serros as by Daniele da Volterra (in exh. cat. Santa Barbara (1983), 34-6, no. II; repr.); Paul Joannides and Catherine Goguel rather thought it to be by Salviati (oral communication), a view shared by Alessandro Nova in exh. cat. Rome and Paris (1998), 68-9 (fig. 4) and 212.

22. Bartsch catalogued it as in the manner of Caraglio (The Illustrated Bartsch, XXVIII, 204). Compare Nova in exh. cat. Rome and Paris (1998), 212, cat. no. 77 , with bibliography.

23. Florence, Uffizi 608F; see Rosenberg (2000), 249, with bibliography, pl. 12. Forlani Tempesti (1991), 278, has stressed the similarities in general composition and style to the Lehman drawing of Jupiter and lo ('Closest to our drawing'). Though the Uffizi sheet is more sketchy, both indeed appear to be by the same hand. It is hard to understand why Mortari (1992), 187, no, 97, accepted the New York drawing as a result of Forlani Tempesti's question-marked attribution, and rejected the Florentine sheet. Though the pen work does lack Cecchino's facility, within the context of compositions all inspired by the copy of Dawn in the British Museum I would include this sheet in Salviati's ceuvre.

24. Illustration and bibliography in Mortari (1992), 123f.

25. Florence, Uffizi inv, 1890, no. 1548. See exh. cat. Florence (1997-98), 197f., with illustration and bibliography. The lying figure at the bottom left is derived from Michelangelo's Dawn seen from a very similar point of view as in Salviati's Edinburgh drawing.

26. Compare Philippe Costamagna, in exh. cat. Rome and Paris (1998), 986 ., cat. no. 9.

27. See Rosenberg (2000), 130-38. On the history of the Academy see Barzman (2000). She asserts (pp. 51-2) that the Academy met in the New Sacristy between autumn 1563 and 1567 , whereas she had written in her dissertation (Barzman $(1985), 208$ ) that 'the members were presently meeting in the capitolo, or chapter room' of San Lorenzo, though without supplying sufficient documentary proof. Since a continuous intercession with 24 hours' prayers for the dead was held from $1561 / 62$ onwards in the chapel (relaxing gradually after 1629) it is likely that the Academy gathered for ordinary sessions somewhere in the Convent of San Lorenzo while the New Sacristy was used for masses; see Vasari's letter to Cosimo I of 16 February 1563, in Frey (1923-40), I, 720, and compare Rosenberg (2000), 135-40.

28. On Naldini's education see Wazbinski ( 1985 ).

29. This is difficult to judge since no thorough study of Naldini's probably very large corpus of drawings has yet been undertaken. The most exhaustive remains Barocchi (1965).

30. Florence, Uffizi, 7500 F (Rosenberg (2000), NZ 332), Lille, Palais des Beaux-Arts 551 (Rosenberg (2000), NZ, 334).

31. Florence, Uffizi, 7456F (Rosenberg (200o), NZ 327), $7461 \mathrm{~F}$ (Rosenberg (2000), NZ 328), 7481Fv. (Rosenberg (2000), NZ 330); London, British Museum, 1946-7-13-368 (Rosenberg (2000), NZ 
335). Some other head studies by Naldini in the Uffizi have great similarities with these sheets, but do not seem to have been drawn from the head of Giuliano: 74518 and $7478 \mathrm{~F}$ (both are illustrated in: Barocchi (1965), pls $96 \mathrm{c}$ and $97 \mathrm{c}$. Wázbiriski $((1985), 290$, note 16) has listed the second one as being after the head of Giuliano, as well as the sketch of a head at the top right of Uffizi $218 s$.

32. Florence, Uffizi 748of (Rosenberg (2000), NZ 329), 7481m. (Rosenberg (2000), NZ 330), and $7486 \mathrm{Fv}$. (Rosenberg (2000), NZ 331 ). Uffizi 218 s (Rosenberg (2000), NZ 333 ) and Lille, Palais des Beaux-Arts, PL 550 (Rosenberg (2000), NZ 334) are both also possibly studies of the right hand of Giuliano seen from above.

33. Casts of those parts of the statues were available, and obviously popular, from the middle of the sixteenth century in Florence, since several drawings after them by different hands (among others Cigoli, Morandini, Bartolomeo Passarotti, and a sheet attributed to Bronzino) have also been preserved. See Rosenberg (2000), NZ 8, 142, 321, 359 (head of Dawn); 58, 322, 325 (right hand of Gutuliano). There is also a great number of studies of Giuliano's head from Tintoretto's workshop. It is difficult to judge whether they are drawn from a plastic reduction or from a plaster cast; see Rossi (1975).

34. Vienna, Albertina inv. no, 378; Rosenberg (2000), NZ 339; colour repr, in exh. cat. Munich (1986), no. 8. The drawing is traditionally attributed to Pontormo; Cox-Rearick ((1964), 412, 1374$)$, rejected this attribution and suggested Federico Zuccaro.

35. Paris, Louvre inv. no. 799; Rosenberg (2000), NZ 336. A report on the provenance, with complete bibliography, will be found in Paul Joannides's forthcoming catalogue of the Michelangelo drawings in the Louvre (Joannides, forthcoming (2003)). He finds it a 'good copy in a style not too far from that of Federico Zuccaro'; Philippe Costamagna suggests an artist in the circle of Vasari (oral communication reported by Joannides).

36. Rosenberg (2000), NZ 342. Provenance: Sir Joshua Reynolds (L. 2364) and William Mayor (L. 2799).

37. Herschel Album, no, 36 , on loan to the Royal Academy of Arts, London (Rosenberg (2000), NZ 339).

38. Princeton, The Art Museum, Princeton University, Bequest of Dan Fellows Platt, acc. nos $1948-$ 761 (Lorenzo) and $1948-762$ (Giuliano). See Rosenberg ( 2000$), \mathrm{NZ}_{337}$ and 338.

39. Windsor, RL 0430. Joannides ((1996), I44f., no. 45) convincingly attributed the drawing to Naldini by comparison with the Princeton sheets. He also has remarked that the highlights were generated 'not by addition of white ... but by erasure, probably with bread'. Subsequently Barbara T. Ross has inspected the drawings in Princeton under a microscope to find out whether this is also the case there. In letters of October 1998 and May 1999 she wrote to me that (in the Giuliano sheet) 'white is present, not for highlights but for defining the subject's clothing and his body contours in the darker areas ... There is stumping or rubbing of the black chalk, in the shadows defining the muscles, but the lights seem more to be absence of black chalk than erasures'. However, 'certain passages - the sides of Giuliano's right ankle, top of his foot, leg bands ...--stand out as "different" and much lighter ... [and] may have been erased ... and white chalk or wash applied, altering the ability of the aging properties of light to get to the paper, and causing it to look fresh and "creamy" in color.' Those erasures 'appear to be executed with an instrument much finer and more precise than I would associate with bread'. A direct confrontation may give further insights.

40. Bean (1966), 26: "Naldini's draughtsmanship is here unusually restrained and "correct", but his personal manner, derived from his master Pontormo, may be observed in the wavering superimposed contours that delineate the hands and feet of the figure'; see also Gibbons (1977), 142; Feinberg (1991), 130; and Pilliod (1994), 392.

41. Bean (1966), 26.

42. Lille, W. 2356 (Giuliano, copy of Princeton 1948-762), W. 2357 (Lorenzo, copy of Princeton, 1948761), W. 2360 (Night, copy of Windsor RL 0430). See Brejon de Lavergnée (1997), no. 1099-1101 (repr.) and Rosenberg (2000), NZ 345-7. Most of these drawings have a traditional attribution to Salviati. Brejon $((1997), 405)$ doubted that all of them are by a single artist and thought that some might be of a later century. Paul Joannides is convinced that they were all drawn in the later sixteenth century (oral communication). The original sequence can be reconstructed through inscriptions on the versos. According to the numbers in the catalogue of Brejon de Lavergnée (1997) this was: $1177,1173,1171,1167,1178,1176,1175,1172,1169,1170,578,1168,1174,1182$, $1159,1163,1164,1086$ and $1087,1181,1161,1160,1205,842,843,1000,583,581,580,579,1180$, $1179,1102,1101,1103,1100,1099,1162,1105,1104,852,577,1112,1110,576,1109,572,573,574$, 575. 1111. All the drawings are the same size $(\mathrm{c}, 26 \times 36 \mathrm{~cm})$, but were made on four different 
types of papers. Two of them are white (watermarks: Briquet 11932/Heawood 2610-11; Briquet $969 /$ Heawood 3954), one is blue (watermark similar to Briquet 1883 and 1884 ), and one is thick and brown (no watermark). According to Briquet and Heawood the watermarks are all to be found in sheets dated to the 1570 and 15805 . A single watermark by itself would not allow a precise date, but the coincidence of three different types used in the same album does give a factual clue. The album is an interesting example of the attitude cultivated in Florence at the end of the cinquecento towards its own past art.

43. Brejon de Lavergnée ( 1997 ), no. $1102-1104$ (repr.) and Rosenberg (2000), NZ 348-50. The Lille copy after the Medici Madonna (W. 2375, Brejon de Lavergnée (1997), no, 1105 (repr.) and Rosenberg (2000), NZ 352), though drawn by the same hand, is sketchier and seems to have been taken from a different prototype, probably not by Naldini.

44 Wazbinski ((1987), L, 94, n, 87) quotes two references for his opinion. (i) The Capitoli et Ordini dell'Accademia (January 1563), ch. XXXI: 'Appresso ci si faccia una libreria per che dell'Arti volessi alla morte sua lasciare Disegni ... le quali si conservino per inventario nelle mani del Proveditore, per farne uno Studio pe i Giovani ...'; (Wázbifiski (1987), II, 432). This paragraph only has in view drawings of the masters to be bequeathed at their death. (ii) Federico Zuccaro's Memoriale per la riforma dell'insegnamento accademico a Firenze (Wázbinski (1987), II, 489-93, dated by this scholar to $157^{8}$ ), where Zuccaro suggests that the 'giovani principianti, desiderosi di far acquisto nel Arte, s'ingegnassero tutti a ogni tornata [this could have been once, twice or four times a month] portar qualche cosa di man loro nell'Accademia, o ritratta dall'opere buone, o dal naturale, o fatta di fantasia loro .... Et cosi a loro si daria occasione d'affaticarsi, et studiare, più che forse non fanno per avventura, perchè l'emulazione tra essi gli faria desti, et vigilanti' (Wázbiriski $(1987), 490)$; Mi piacerebbe ancora vi fusse un libro, dove si riponesse et salvasse nell'Accademia tutti i disegni miglion di detti Giovani con i nomi loro, si per inanimirli a loro, come gl'altri appresso, et di mano in mano vedrebbono li loro acquisti ...' (Wázbiríki (1987), 492). Since Zuccaro makes suggestions for reform, it means that this was not in use before. Moreover his idea is concerned with the improvement of the education of the young artists and not with an entrance competition.

45. For the reproduction of the Sistine Chapel see exh. cat. Rome (1991), which includes (pp. 17-30) a general overview on prints after Michelangelo.

46. By Cornelis Bos (d. 1556); see Schéle (1965), 129, no. 49a. The statue was bought in Rome by Francesco I de' Medici in 1572; see Eike Schmidt in exh. cat. Florence (1999), 362.

47. The earliest ones are both dated 1547: Nicolas Beatrizet (see E. Borea, in exh. cat. Florence (1980a), no. 562) and Giulio Bonasone (The Ilistrated Bartsch, XXVIII, 257).

48. The earliest one by Beatrizet (The Illustrated Bartsch, XXIX, 266).

49. A general view of the whole Tomb by an anonymous printmaker, published by Salamanca in 1554 (Borea 1980, no. 600). The earliest single print of the Moses is attributed to Beatrizet: De Tolnay (1943-60), IV, 102 and 105, fig. 281; Schele (1965), 201, no. 218, and pl. 59.

50. Borea (1980).

51. Exh. cat, Rome (1991), $29 f$.

52. See Landau and Parshall (1994), 302-08.

53. Sellink (2000), I, xxvi-xxvii.

54 Sellink (2000), I, nos 218 and 217 .

55. Sellink (2000), I, no. 219 .

56. Sellink (2000), I, no. 216 .

57. This applies to all sculptures except for the Lille copies of Dusk (W. 2367) and of the Madonna (W. 2375). Since the Madonna does not appear to have been copied after a Naldini drawing this is no surprise. In the case of Dusk Cort certainly used a different drawing as his model: this might have been a second sheet by Naldini or by somebody else. It is worth mentioning that a further drawing after Dusk dated in 1574 and hence later (and moreover from a very different viewpoint) has been attributed to Cort himself (see Laura Corti in exh. cat. Montreal (1992), 250, and Rosenberg (2000), NZ 151).

58. Lille, Palais des Beaux-Arts W. 2368. See Rosenberg (2000), NZ 350, pl. 24 -

59. In comparison with the sculptures only a few elevations of the architecture of the New Sacristy can be traced. Two anonymous sheets from the second half of the sixteenth century include sketches of sculptures: Kunstmuseum Düsseldorf (Sammlung der Kunstakademie). KA (FP) 141, Elevation of two wall sides (altar and Giuliano Tomb with faint sketch of statues), $41.1 \times 28.7 \mathrm{~cm}$, pen 
and brown ink over black pencil, according to Paul Joannides (in a letter of October 200o) close to Zucchi; Uffizi 1918A, Elenation of the wall with Lorenzo Tomb, $28.5 \times 19 \mathrm{~cm}$, pen and brown ink over black pencil, altogether more sketchy. There are some more accurate elevations of the chapel from the seventeenth century in the Uffizi: $3892 \mathrm{~A}$ (Three walls of the New Sucristy) and a bound manuscript by Nelli with detailed representations of Michelangelo's architecture in San Lorenzo (3696-3739A, see note 71, below).

6o. Meijer (1987) and Sellink (2000), no. 229 .

61. 'Corn(e). Cort fe,' on Sellink (2000), nos, 216 and 217, as well as '1570' on Sellink (2000), nos 216-18.

62. There are six different states of Sellink (2000), no. 216 (Tomb of Piero and Giovanni de' Medici). They allow one to follow the successive editions (by Andrea Vaccari, Philippe Thomassin and Giovanni Giacomo de Rossi). 216/V1 corresponds to $217 / 11,218 / 11$ and $219 / 11$ all of them included in Domenico de Rossi, Studio d'architeftura civile sopra vari ornamenti di cappelle, e diversisopolcri tratti da piu chiese di Roma [...]. Rome, 1621. They bear long explanatory inscriptions: no. 217 'IL CREPUSCOLO / L'AURORA / DEPOSTTO DEL DUCA LORENZO DE MEDICI FIGURATO PER LO PENSIBRO NELLA CAPPELLA DI S. LORENZO IN FIKENZE ARCHITETTURA, E

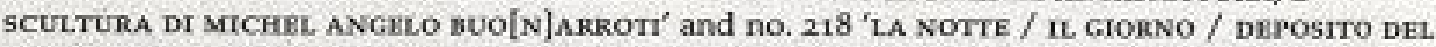
DUCA GIULIANO DE MEDICI FIGURATO PER LA VIGILANZA NELLA CAPPELLA DI S. LORENZO IN FIRENZE ARCHITETTURA, F SCULTURA DI MICHEL ANGELO BUO[N]ARROTI'. See Sellink (2000), III, 145-6, and compare Grelle Iusco (1996), 400 and 451, and Rosenberg (2000), 38-9, n. 92 (which should be corrected acoordingly).

63. Borea (1979), 395; Meijer (1987), 173; Borea in exh. cat. Rome (1991), 28; Corti in exh. cat. Montreal (1992), 250, and exh. cat. Rotterdam (1994), 213-

64. Wazbinski (1983), 69, and Wazbinski (1987), I, $109 f$.

65. Meijer $(1987), 172$. The plate is now in a private collection in Holland. The plates of the Medici Tombs are no longer extant (they may have perished in the Roman Calcografia during the purges of the early nineteenth century).

66. A comparable and more distinct ennobling through the use of antique ruins can be found in Beatrizet's frequently copied reproduction of the St Peter's Pietà, See note 47 , above, and exh. cat. Florence (1987), 109f., no. 46.

67. Landau and Parshall (1994), 163-5.

68. Compare exh. cat., Rome (1991), 34-5, nos 1-4 and figs 30,33 and 36 .

69. The very first systematic reproductions of the central images of Genesis are part of a project that was started in the 1770 . The prints were mainly executed by Domenico Cunego. See exh. cat. Rome (1991), nos 32-4

70. On the emergence and development of print reproduction in Italy, see Borea (1979), and Landau and Parshall (1994), 103-68 and 305ff.

71. In the very first monographic 'publication' of Michelangelo's architecture at San Lorenzo (Opere d'Architettura di Michelagnolo Buonarnoti fatte per S. Lorenzo di Finenze misurate e disegnate da Giovunni Battista Nelli, Uffizi 3696-3739a), Cort's print of the Giuliano de' Medici Tomb served as a model for the statues in the elevation of the monument $(\mathrm{p}, 10=3706 \mathrm{~A}, 42.0 \times 27.5 \mathrm{~cm}$, pen and brown ink, wash and grey ink). The dedication of this manuscript book is dated 10 April 1687 (Rosenberg (2000), p. 85, n. 170, with erroneous date ' $\left.1696^{\prime}\right)$. The Richardsons $((1728), 136)$ still referred to Cort's prints to illustrate their account of the chapel. 